\title{
MODELING THE SYSTEM OF SOCIAL STABILITY THROUGH THE FOOD SAFETY PARADIGM
}

\author{
Federica Ciccullo ${ }^{1}$, Olena Shebanina ${ }^{2}$, Alla Burkovska ${ }^{3}$, \\ Tatyana Lunkina ${ }^{4}$, Anna Burkovska ${ }^{5}$ \\ ${ }^{1}$ Assistant Doctor, Politecnico di Milano, Via Lambruschini 4C-20156 Milan, Italy. \\ Phone+393406260483.E-mail federica.ciccullo@polimi.it \\ ${ }^{2}$ Doctor of Economics, Professor, Mykolayiv National Agrarian University, Georgiy Gongadze str. \\ 3a, 54020 Mykolayiv, Ukraine.Phone+380504932907.E-mail shebanina@mnau.edu.ua \\ ${ }^{3}$ Assoc. Prof., Mykolayiv National Agrarian University.Georgiy Gongadze str. 9, 54020 Mykolaiv, \\ Ukraine. Phone +380973841769. E-mail allaburkovska2010@ gmail.com \\ ${ }^{4}$ Assoc. Prof., Mykolayiv National Agrarian University.Georgiy Gongadze str. 9, 54020 Mykolaiv, \\ Ukraine. Phone +380679636126. E-mail lunkina_tanya@i.ua \\ ${ }^{5}$ PhD student, Mykolayiv National Agrarian University, Georgiy Gongadze str. 3a, 54020 Mykolayiv, \\ Ukraine. Phone +380974828736. E-mail anna.burkovskaya12@gmail.com
}

Received 1910 2019; accepted 20122019

On a country-wide scale, the problem of food security is closely connected with the general doctrine of national security. The article analyzes the causes and factors of the features and patterns of food security issues as a component of international economic security; the essence and content of food security as an integral part of socio-economic development in the context of international economic security are presented. The purpose of the article is to determine the influence of economic and social factors on the level of food security of the population. The methodic of work is based on the construction of a correlation-regression model of the influence of a certain range of factors on food safety of households in the context of providing social stability. During the study it was used the information obtained from official statistical sources and respondents survey. The results of the study represent the dependence of the food security of the population of Italy and Ukraine on such factors as the level of income, the importance of value when choosing products, the availability of family members who are starving, etc.

Keywords: correlation-regression analysis, food security, household incomes, questionnaires, social policy, social stability.

JEL Codes: Q12, Q14.

\section{Introduction}

The intensification of the globalization processes, the escalation of security problems in many regions of the world become objective preconditions for the revision of the state of national security in general and economic security with all its components as its basis.

Copyright (C) 2019 The Authors. Published by Vytautas Magnus University. This is an open-access article distributed under the terms of the Creative Commons Attribution-NonCommercial 4.0 (CC BY-NC 4.0) license, which permits unrestricted use, distribution, and reproduction in any medium, provided the original author and source are credited. The material cannot be used for commercial purposes.

* Corresponding author 
The problem of providing humanity with food currently holds one of the leading places in the hierarchy of global problems. Food safety of the countries is an indispensable condition and a guarantee of preservation of its sovereignty and independence, which ensures sustainable social and economic development as well as formation of high standards and quality of life of the population and reproduction of human capital.

On a country-wide scale, the problem of food security is closely connected with the general doctrine of national security. From the perspective of the philosophy of social stability, the task of providing the population with food is not only the one element. However, this element can be called the main one, because in practice it represents a guarantee of internal social stability and stability of the ruling regime in case of an external or internal cataclysm.

The study of food security issues of various hierarchical ranks, as well as its principles, factors and threats, is represented in a large number of scientific works, in particular Ickowitz, Powell, Rowland, Jones, Sunderland (2019), Mwungu, Shikuku, Atibo, Mwongera (2019), Alexandria, Lucaa, Kevorchiana (2015), Babych and Kovalenko (2018) and others.

In their papers Blumberg, Bialostosky, Hamilton, Briefel (1999) suggest the usage of the respondent questionnaires to identify the current state of food security of the population and discover the factors that have the greatest impact on its provision. The questionnaire composed by scientists was developed with a nonlinear factor analysis technique that created a multidimensional scale in which all items load equally upon the single factor.

Some scientists such as Candel (2018), Abdullah, Shah, Ali, Ahmad, Din, Ilyas (2017) emphasize that food security has many dimensions, ranging from global, regional, local and household to the individual level. Scientists point out that food security is seemed to be a multidimensional phenomenon encompassing climate change, civil conflicts, natural disasters and social norms.

A large-scale study of the influence of social determinants on the formation of food security of households was carried out in papers of Agidev and Singh (2018), Feleke, Kilmer, Gladwin (2005) and others. Scientists have established the dependence of the food security status on the size of households, age of the head of the family, level of education, gender, access to the Internet and number of the financial instruments in disposal of individual households. In papers of Shebanina, Klyuchnik, Burkovska and Caruso is formulated the relationship between the economic affordability of food and the average monthly wage in the country, as well as arrears in its payment.

Anema, Fielden, Castleman, Grede, Heap and Bloem (2014) observed in their papers main dimensions and components of food security which enables more specific measurement and analysis of the nature of food security or insecurity among populations. These authors developed the typology which can be useful for assessing the extent to which the food people consume meets their needs and for identifying specific gaps in food security that need to be addressed. In papers of Leroy, Ruel, 
Frongillo, Harris and Ballard (2015) the main indicators of food security are studied that brought clarity in the assessment of the food access dimension of food security at the household and individual level.

The purpose of the paper is to conduct investigation of the influence of economic and social factors on the level of food security of the population and to identify the most significant among them. The research object implies the level of food security in Italy and Ukraine. The research subject includes the factors that affect the food security (the size and sources of monthly income of the population, gender, age, level of education, household size, availability of the Internet access, etc.)

The methodic of this article is based on the construction of a correlationregression model of the influence of a certain range of factors on food security of households in the context of providing social stability. Study period: from March to May 2019. The survey involved 402 respondents from Italy and 484 respondents from Ukraine aged 17-30. During the study it was used the information obtained from statistical sources and respondents survey.

The questionnaires for Italian and Ukrainian respondents consisted of 17 and 13 questions, of which 7 questions with several suggested answer choices; 5 yes-no questions; 4 questions to clarify the degree of agreement with the statement and 1 question with the proposed frequency matrix of answers (4 questions to clarify the degree of agreement with the statement were presented just in the questionnaire for Italian respondents. These questions were asked as additional due to some differences in the level of socio-economic development of Italy and Ukraine).

\section{Results and discussion}

The intensification of the processes of globalization, the escalation of security problems in many regions of the world become objective preconditions for revision of the state of national security in general and its basis - economic security with all its components.

Food security of the countries is an indispensable condition and a guarantee of preservation of its sovereignty and independence, ensuring of sustainable social and economic development, formation of high standards and quality of life of the population, reproduction of human capital.

Given the need to determine the impact of economic and social factors on the level of food security of the population, consider their definitions in Table 1, with reference to relevant literary sources. 
Table 1. Basic definitions

\begin{tabular}{|l|l|l|l|}
\hline Concept & \multicolumn{1}{|c|}{ Definition } & $\begin{array}{l}\text { References to } \\
\text { the literature } \\
\text { sources }\end{array}$ & $\begin{array}{l}\text { Examples that were } \\
\text { used during the study }\end{array}$ \\
\hline $\begin{array}{l}\text { Economic } \\
\text { factors }\end{array}$ & $\begin{array}{l}\text { Characterize the ability of consumers to } \\
\text { mobilize resources to provide themselves } \\
\text { and households with food, which guarantees } \\
\text { their economic independence }\end{array}$ & (Chavas, 2017) & $\begin{array}{l}\text { The size and sources of } \\
\text { monthly income of the } \\
\text { population }\end{array}$ \\
\hline $\begin{array}{l}\text { Social } \\
\text { factors }\end{array}$ & $\begin{array}{l}\text { Includes a range of factors of anthropogenic } \\
\text { origin, which determine the quality of } \\
\text { human life in society and exist inseparably } \\
\text { with people, social structures and } \\
\text { institutions }\end{array}$ & $\begin{array}{l}\text { (Cheeseman, } \\
\text { 2016) }\end{array}$ & $\begin{array}{l}\text { Gender, age, level of } \\
\text { education, household } \\
\text { size, availability of the } \\
\text { Internet access }\end{array}$ \\
\hline $\begin{array}{l}\text { The level } \\
\text { of food } \\
\text { security of } \\
\text { the } \\
\text { population }\end{array}$ & $\begin{array}{l}\text { It is considered as a subjective assessment of } \\
\text { the own diet and food behavior of the } \\
\text { population, taking into account the threat of } \\
\text { hunger and nutritional inadequacy }\end{array}$ & $\begin{array}{l}\text { (Blumberg, } \\
\text { Bialostosky, } \\
\text { Hamilton and } \\
\text { Briefel, } \\
\text { 1999) }\end{array}$ & $\begin{array}{l}\text { The presence or } \\
\text { absence of precedents } \\
\text { for restrictions on the } \\
\text { consumption of food } \\
\text { due to lack of funds for } \\
\text { its purchase }\end{array}$ \\
\hline
\end{tabular}

Hidboro, Hoddinott, Kumar and Olivier (2018) examine food safety from the standpoint of the legal approach, according to which the nutrition of an individual, family, social group depends on what they can buy to meet their food needs. These scientists paid special attention to the social aspect of the food problem, concluded that food security depends not only on the production of products and agricultural activities, but also on the solution of several problems, including the ability of individuals to obtain food. In turn, the economic availability of food products is formed as a component of the social policy of the state, which is realized through the social protection of citizens.

Thus, social protection of the population is a state support for certain categories of population that can be negatively affected by market processes, providing an appropriate standard of living by providing legal, financial, material assistance to individual citizens (the most vulnerable groups of the population), as well as the creation of social guarantees for economically active part of the population, ensuring the living conditions and work of citizens, acceptable for the country, including through the establishment of social standards (Bruck, d'Errico, 2019).

Creation of an effective model of social protection of the population promotes not only the stabilization of relations in society, but also the improvement of the state of food security of the country. Consider the dynamics of the current state of social security of the population of the countries under study in Table 2. 
Table 2. The state of social security of the population in the dynamics

\begin{tabular}{|l|c|c|c|c|}
\hline \multirow{2}{*}{ Indexes } & \multicolumn{3}{|c|}{ Years } \\
\cline { 2 - 5 } & 2014 & 2015 & 2016 & 2017 \\
\hline Italy & 625.15 & 630.57 & 636.81 & 651.13 \\
\hline $\begin{array}{l}\text { Relative poverty threshold (monthly expenditure in } \\
\text { euros) }\end{array}$ & - & 0.9 & 1.0 & 2.2 \\
\hline $\begin{array}{l}\text { Growth of the relative poverty threshold relative to the } \\
\text { previous period, \% }\end{array}$ & 2097.17 & 2123.08 & 2136.75 & 2151.17 \\
\hline $\begin{array}{l}\text { The average monthly salary, according to collective } \\
\text { labor contracts, in euros }\end{array}$ & - & 1.2 & 0.6 & 0.7 \\
\hline $\begin{array}{l}\text { Growth of the average salary relative to the previous } \\
\text { period, \% }\end{array}$ & -1176 & 1227.33 & 1388.08 & 1603.67 \\
\hline Consumer price index relative to the previous period, \% & 0.241 & 0.039 & -0.094 & 1.227 \\
\hline Ukraine & - & 4.4 & 13.1 & 15.5 \\
\hline Subsistence minimum, UAH & 3470.08 & 4207.33 & 5187.33 & 7105.42 \\
\hline $\begin{array}{l}\text { Growth of the subsistence minimum relative to the } \\
\text { previous period, \% }\end{array}$ & - & 21.2 & 23.3 & 37.0 \\
\hline Average salary, UAH & 24.9 & 43.3 & 12.4 & 13.7 \\
\hline $\begin{array}{l}\text { Growth of the average salary relative to the previous } \\
\text { period, \% }\end{array}$ & & & \\
\hline Consumer price index relative to the previous period, \% & 24.4 & \\
\hline
\end{tabular}

Source: calculated using (Households..., 2017) and (State..., 2019).

Thus, the growth of income in Italy is faster than the inflationary processes that have an impact on ensuring a solvent demand for consumer goods. The increase in the average wage in Ukraine is substantially higher than the growth rate of food prices, while the growth of the subsistence minimum is only indexed by the level of inflation.

Depending on the level of economic development, countries have varying in scale and content of the problem in ensuring food security of the population. Thus, for countries with high GDP per capita, the priority tasks for achieving a high level of food security are to ensure the normative quality of products and the environmental safety of its production. At the same time, countries with low rates of economic development have significant problems in ensuring effective food supply and the economic availability of meals.

Taking into account the hypothesis that developing countries have the potential for faster growth than developed countries due to higher profitability of factors of production, as well as the tendency to copy the methods of production, technologies and institutions that are characteristic of developed economies, we will calculate the period which is necessary for Ukraine to achieve the level of economic development of Italy in Table 3, using the formula:

$$
\mathrm{T}=\ln \left(Y_{u} / Y_{i}\right) / \ln \left(\left(1+g_{i}\right) /\left(1+g_{u}\right)\right)
$$


where $\mathrm{T}$ - time period, years; $Y_{u}$ - GDP per capita in Ukraine, USD; $Y_{i}$ - GDP per capita in Italy, USD; $g_{u}$ - growth of GDP per capita in Ukraine, $\% ; g_{i}$ - growth of GDP per capita in Italy, $\%$.

Table 3. Calculation of the possible period of convergence of the economies of Italy and Ukraine

\begin{tabular}{|l|c|c|c|c|}
\hline Indexes & 2014 & 2015 & 2016 & 2017 \\
\hline GDP per capita in Ukraine, USD & 3105 & 2125 & 2186 & 2640 \\
\hline Growth of GDP per capita in Ukraine, \% & - & -31.6 & 2.9 & 20,8 \\
\hline GDP per capita in Italy, USD & 35397 & 30180 & 30669 & 31953 \\
\hline Growth of GDP per capita in Italy, \% & - & -14.7 & 1.6 & 4.2 \\
\hline Possible convergence period, years & $\mathrm{x}$ & $\mathrm{x}$ & 216 & 17 \\
\hline
\end{tabular}

Source: calculated using (GDP..., 2018).

Thus, during the period under study, the rate of economic growth in Ukraine demonstrates positive dynamics, which allows us to assume that the economic indicators of Ukraine's development are approaching the indicators of Italy under the conditions of preserving the existing growth rates for 17 years. Under these conditions, the challenges accompanying the process of food security in Ukraine should be addressed considering the combination of factors that contribute to the creation of social stability at all levels, including food security.

To determine the impact of the factors discussed above on the level of food security of the population we conducted a survey of more than 400 respondents from Italy and Ukraine (the study was conducted among students of Milan Polytechnic (Italy) and the Mykolayiv National Agrarian University (Ukraine)), the minimal number of which was determined by the formula:

$$
\mathrm{n}=\frac{t^{2} * p(1-p)}{m^{2}}
$$

where $\mathrm{n}-$ is the sample size; $\mathrm{t}$ - is the confidence level; $\mathrm{p}-$ is estimated prevalence; $\mathrm{m}$ - is the confidence interval. Thus:

$$
\mathrm{n}=\frac{1,96^{2} * 0,5(1-0,5)}{0,05^{2}}=384 .
$$

The survey of respondents was conducted through the questioning in personal communication, as well as posting the developed questionnaire on the electronic resources of universities. The questionnaire for collecting information contains the following questions presented in Table 4. 
Table 4. The content of the questionnaire

\begin{tabular}{|c|c|c|c|c|}
\hline № & Question & Options for answers & $\begin{array}{l}\text { Answers of } \\
\text { respondents in } \\
\text { Italy }\end{array}$ & $\begin{array}{l}\text { Answers of } \\
\text { respondents in } \\
\text { Ukraine }\end{array}$ \\
\hline \multirow[t]{2}{*}{1.} & \multirow[t]{2}{*}{ Please indicate your gender: } & Male & 270 & 250 \\
\hline & & Female & 132 & 234 \\
\hline \multirow[t]{6}{*}{2.} & \multirow{6}{*}{$\begin{array}{l}\text { Please specify the number of } \\
\text { people in your household: }\end{array}$} & 1 & 28 & 51 \\
\hline & & 2 & 58 & 116 \\
\hline & & 3 & 88 & 149 \\
\hline & & 4 & 154 & 104 \\
\hline & & 5 & 52 & 41 \\
\hline & & More than 5 & 22 & 23 \\
\hline \multirow[t]{3}{*}{3.} & \multirow{3}{*}{$\begin{array}{l}\text { Indicate the level of your } \\
\text { English proficiency: }\end{array}$} & Elementary & 14 & 141 \\
\hline & & Intermediate & 190 & 228 \\
\hline & & Advanced & 198 & 115 \\
\hline \multirow[t]{2}{*}{4.} & \multirow{2}{*}{$\begin{array}{l}\text { Do you have any permanent } \\
\text { Internet access? }\end{array}$} & Yes & 386 & 441 \\
\hline & & No & 16 & 43 \\
\hline \multirow[t]{2}{*}{5.} & \multirow{2}{*}{$\begin{array}{l}\text { In the last } 12 \text { months have the } \\
\text { members of your family ever } \\
\text { faced a situation in which they } \\
\text { could not afford to buy } \\
\text { enough food to satisfy their } \\
\text { basic needs? }\end{array}$} & Yes & 6 & 163 \\
\hline & & No & 396 & 321 \\
\hline \multirow[t]{2}{*}{6.} & \multirow{2}{*}{$\begin{array}{l}\text { During the last } 12 \text { months, } \\
\text { have you ever faced a } \\
\text { situation in which you could } \\
\text { not afford to buy enough food } \\
\text { to satisfy your basic needs? }\end{array}$} & Yes & 12 & 144 \\
\hline & & No & 390 & 340 \\
\hline \multirow[t]{4}{*}{7.} & \multirow[t]{4}{*}{ What is your monthly income? } & $\begin{array}{l}\text { Less than } 2000 \\
\text { UAH (Ukraine); } \\
\text { Less than } 651 \text { euros } \\
\text { (Italy); }\end{array}$ & 290 & 84 \\
\hline & & $\begin{array}{l}\text { 2001- } 4200 \text { UAH } \\
\text { (Ukraine); 651,01- } \\
2195 \text { euros (Italy); }\end{array}$ & 94 & 180 \\
\hline & & $\begin{array}{l}4201-10000 \text { UAH } \\
\text { (Ukraine); } \\
2195,01-2410 \\
\text { euros (Italy); }\end{array}$ & 8 & 168 \\
\hline & & $\begin{array}{l}\text { More than } 10000 \\
\text { UAH (Ukraine); } \\
\text { More than } 2410 \\
\text { euros (Italy); }\end{array}$ & 10 & 52 \\
\hline \multirow[t]{5}{*}{8.} & \multirow{5}{*}{$\begin{array}{l}\text { Indicate the main source of } \\
\text { funds for your monthly } \\
\text { maintenance: }\end{array}$} & Salary & 94 & 205 \\
\hline & & Profit from business & 12 & 39 \\
\hline & & Scholarship & 48 & 102 \\
\hline & & Pension & - & 20 \\
\hline & & $\begin{array}{l}\text { Unemployment } \\
\text { benefits }\end{array}$ & - & 8 \\
\hline
\end{tabular}


Modeling the System of Social Stability through the Food Safety Paradigm Federica Ciccullo, Olena Shebanina, Alla Burkovska, Tatyana Lunkina, Anna Burkovska

\begin{tabular}{|c|c|c|c|c|}
\hline & & $\begin{array}{l}\text { Financial support } \\
\text { provided by } \\
\text { relatives }\end{array}$ & 228 & 107 \\
\hline & & $\begin{array}{l}\text { Patronage } \\
\text { assistance }\end{array}$ & 14 & 3 \\
\hline & & $\begin{array}{l}\text { Passive income } \\
\text { (dividends, interest, } \\
\text { etc.). }\end{array}$ & 6 & 8 \\
\hline \multirow[t]{13}{*}{9.} & \multirow{13}{*}{$\begin{array}{l}\text { What does your normal diet } \\
\text { include and how often? }\end{array}$} & \multicolumn{3}{|c|}{ Daily / Weekly / Monthly / Quarterly / I do not use it } \\
\hline & & $\begin{array}{l}\text { Meat and meat } \\
\text { products }\end{array}$ & $170 / 202 / 10 / 4 / 16$ & $151 / 225 / 58 / 5 / 45$ \\
\hline & & $\begin{array}{l}\text { Milk and dairy } \\
\text { products }\end{array}$ & 260/104/14/8/16 & $180 / 184 / 47 / 7 / 66$ \\
\hline & & Eggs & $36 / 296 / 48 / 8 / 14$ & $224 / 141 / 29 / 4 / 86$ \\
\hline & & $\begin{array}{l}\text { Cereals and } \\
\text { legumes }\end{array}$ & $164 / 184 / 22 / 10 / 22$ & $216 / 160 / 36 / 10 / 62$ \\
\hline & & Potatoes & $32 / 270 / 74 / 6 / 20$ & $243 / 143 / 41 / 2 / 55$ \\
\hline & & $\begin{array}{l}\text { Vegetables and } \\
\text { melons }\end{array}$ & $272 / 94 / 12 / 4 / 20$ & $184 / 159 / 50 / 5 / 86$ \\
\hline & & Fruits and berries & $278 / 86 / 16 / 2 / 20$ & $126 / 185 / 55 / 21 / 97$ \\
\hline & & Sugar & $238 / 80 / 38 / 10 / 36$ & $239 / 130 / 26 / 8 / 81$ \\
\hline & & Oil & $330 / 54 / 2 / 4 / 10$ & $236 / 130 / 35 / 5 / 78$ \\
\hline & & $\begin{array}{l}\text { Fish and Fish } \\
\text { Products }\end{array}$ & $24 / 266 / 62 / 20 / 30$ & $116 / 190 / 64 / 21 / 93$ \\
\hline & & $\begin{array}{l}\text { Bread and flour } \\
\text { products }\end{array}$ & $296 / 72 / 18 / 4 / 12$ & $257 / 112 / 28 / 2 / 85$ \\
\hline & & Confectionery & $150 / 172 / 48 / 10 / 22$ & $141 / 169 / 47 / 11 / 116$ \\
\hline 10. & $\begin{array}{l}\text { What is the main reason why } \\
\text { you limit your food } \\
\text { consumption? }\end{array}$ & $\begin{array}{l}\text { I limit myself in } \\
\text { food because of } \\
\text { lack of funds }\end{array}$ & 8 & 100 \\
\hline & & $\begin{array}{l}\text { I limit myself in } \\
\text { food because of } \\
\text { ethical-religious } \\
\text { beliefs }\end{array}$ & 14 & 18 \\
\hline & & $\begin{array}{l}\text { I limit myself in } \\
\text { food because of the } \\
\text { doctor's } \\
\text { recommendations }\end{array}$ & 28 & 41 \\
\hline & & $\begin{array}{l}\text { I limit myself in } \\
\text { food because of my } \\
\text { own desire to lose } \\
\text { weight }\end{array}$ & 122 & 34 \\
\hline & & $\begin{array}{l}\text { I do not restrict } \\
\text { myself in eating }\end{array}$ & 230 & 191 \\
\hline 11. & $\begin{array}{l}\text { In case of increasing your } \\
\text { monthly income which of }\end{array}$ & $\begin{array}{l}\text { Meat and meat } \\
\text { products }\end{array}$ & 186 & 217 \\
\hline & $\begin{array}{l}\text { these product groups would } \\
\text { you more often consume? }\end{array}$ & $\begin{array}{l}\text { Milk and dairy } \\
\text { products }\end{array}$ & 10 & 61 \\
\hline & & Eggs & 0 & 14 \\
\hline & & $\begin{array}{l}\text { Cereals and } \\
\text { legumes }\end{array}$ & 6 & 10 \\
\hline
\end{tabular}




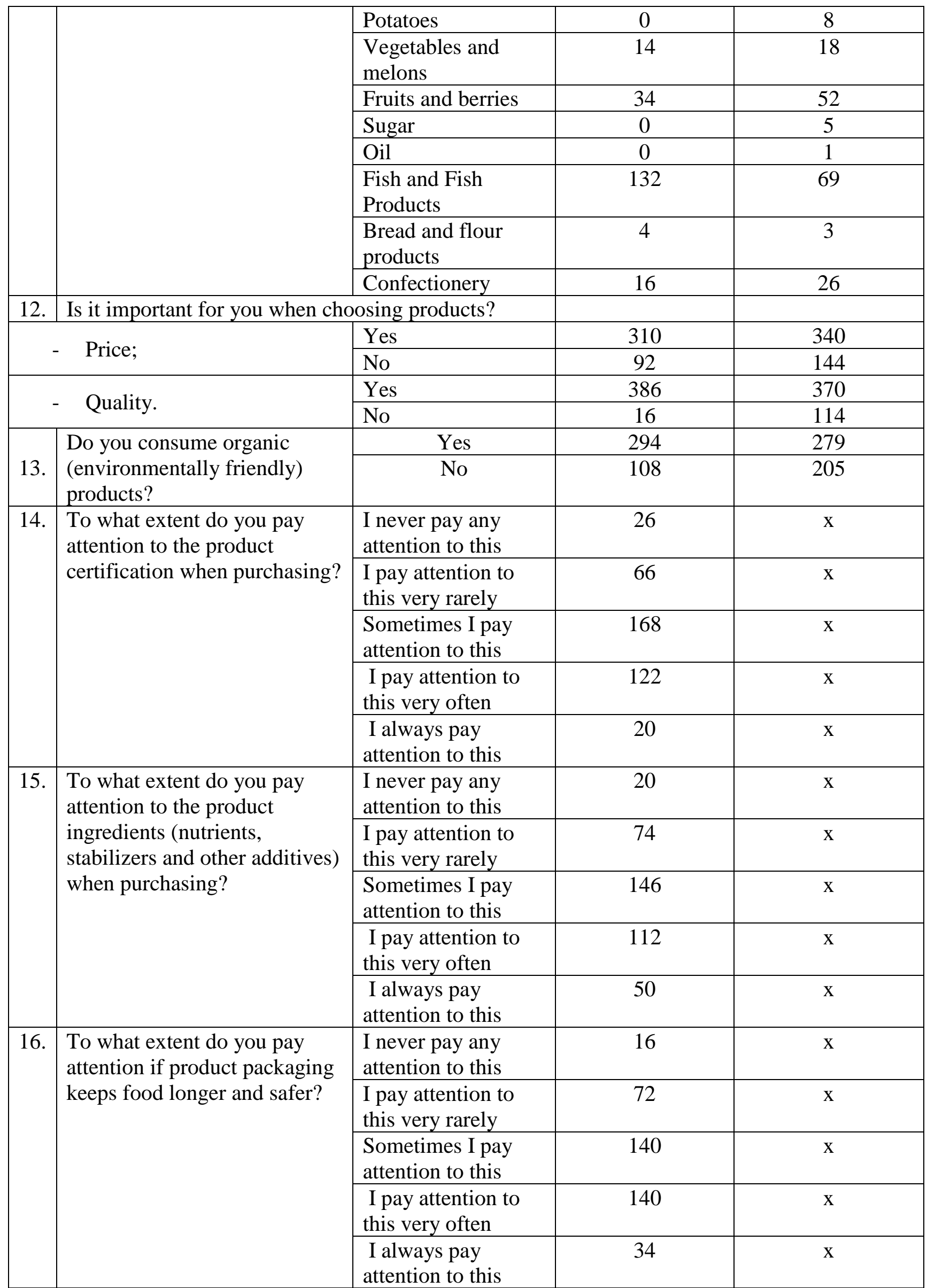


Modeling the System of Social Stability through the Food Safety Paradigm Federica Ciccullo, Olena Shebanina, Alla Burkovska, Tatyana Lunkina, Anna Burkovska

\begin{tabular}{|c|c|c|c|c|}
\hline \multirow{5}{*}{17.} & \multirow{5}{*}{$\begin{array}{l}\text { To what extent do you pay } \\
\text { attention if product packaging } \\
\text { is made of sustainable } \\
\text { (innovative recycled and } \\
\text { recyclable) materials? }\end{array}$} & $\begin{array}{l}\text { I never pay any } \\
\text { attention to this }\end{array}$ & 40 & $\mathrm{X}$ \\
\hline & & $\begin{array}{l}\text { I pay attention to } \\
\text { this very rarely }\end{array}$ & 86 & $\mathrm{x}$ \\
\hline & & $\begin{array}{l}\text { Sometimes I pay } \\
\text { attention to this }\end{array}$ & 138 & $\mathrm{X}$ \\
\hline & & $\begin{array}{l}\text { I pay attention to } \\
\text { this very often }\end{array}$ & 100 & $\mathrm{x}$ \\
\hline & & $\begin{array}{l}\text { I always pay } \\
\text { attention to this }\end{array}$ & 38 & $\mathrm{x}$ \\
\hline
\end{tabular}

After processing the results of the questionnaires and turning them into binary, numeric and categorical variables using the JASP statistical program, we obtained the following results presented in the table 5 .

Table 5. Model summary (based on the survey in Italy and Ukraine)

\begin{tabular}{|c|l|c|c|c|c|}
\hline \multirow{3}{*}{ Model } & \multicolumn{2}{|c|}{ Variables } & \multicolumn{2}{c|}{ Italian dataset } & \multicolumn{2}{c|}{ Ukrainian dataset } \\
\cline { 3 - 6 } & & $\begin{array}{c}\text { Correlati } \\
\text { on Index }\end{array}$ & p-value & $\begin{array}{c}\text { Correlati } \\
\text { on Index }\end{array}$ & p-value \\
\hline \multirow{4}{*}{0} & Monthly income & -0.134 & 0.007 & -0.378 & $<.001$ \\
\cline { 2 - 6 } & Value of Price & 0.130 & 0.009 & 0.196 & $<.001$ \\
\cline { 2 - 6 } & Sources of money & 0.094 & 0.061 & -0.002 & 0.959 \\
\hline \multirow{5}{*}{1} & Gender & -0.034 & 0.503 & 0.043 & 0.351 \\
\cline { 2 - 6 } & Number of household members & 0.116 & 0.023 & -0.024 & 0.601 \\
\cline { 2 - 6 } & Level of your English proficiency & 0.044 & 0.385 & 0.072 & 0.119 \\
\cline { 2 - 6 } & Permanent Internet access & -0.052 & 0.304 & -0.034 & 0.457 \\
\cline { 2 - 6 } & Household members restricted in eating & 0.473 & $<.001$ & 0.395 & $<.001$ \\
\cline { 2 - 6 } & Monthly income & -0.097 & 0.050 & -0.295 & $<.001$ \\
\cline { 2 - 6 } & Value of Price & 0.156 & 0.002 & 0.101 & 0.027 \\
\cline { 2 - 6 } & Value of Quality & -0.017 & 0.737 & -0.015 & 0.740 \\
\cline { 2 - 6 } & Consumption of organic products & 0.133 & 0.009 & -0.073 & 0.111 \\
\cline { 2 - 6 } & Sources of money & 0.100 & 0.050 & -0.003 & 0.950 \\
\cline { 2 - 6 } & Certification & -0.060 & 0.241 & $\mathrm{x}$ & $\mathrm{x}$ \\
\cline { 2 - 6 } & Ingredients & -0.085 & 0.093 & $\mathrm{x}$ & $\mathrm{x}$ \\
\cline { 2 - 6 } & Product packaging & 0.081 & 0.111 & $\mathrm{x}$ & $\mathrm{x}$ \\
\cline { 2 - 6 } & Sustainable materials & 0.096 & 0.058 & $\mathrm{x}$ & $\mathrm{x}$ \\
\hline
\end{tabular}

Source: built using JASP statistics

On the basis of the obtained results it can be concluded that the most significant factors influencing the food security of the population, expressed in the absence of precedent for hunger due to the inability to purchase food because of lack of funds, are:

- monthly income (negative correlation indicates that the higher the income, the less probability of respondent's hunger);

- value of prices when choosing food (direct correlation indicates that the more consumers consider the price of food, the greater the probability of the respondent's hunger); 
- the number of family members (direct correlation indicates that the larger the size of the household, the greater the probability of the respondent's hunger);

- the number of famine-affected family members (direct correlation indicates that the more likely the hunger of a household member is, the greater the probability of a respondent's hunger), etc.

\section{Conclusions}

Fighting hunger is recognized as a priority task for international economic cooperation of nations, and therefore food security belongs to the global category, since it is not enough for individual countries to solve it, but a well-established cooperation between the world community is required, regardless of social and economic development. Therefore, in conditions of economic development in Ukraine and in the process of implementation of agrarian reform, considerable attention should be paid to the borrowing of international experience in legislative regulation of food security issues.

Depending on the level of economic development, countries have varying in scale and content of the problem in ensuring food security of the population. Thus, for countries with high GDP per capita, the priority tasks for achieving a high level of food security are to ensure the normative quality of products and the environmental safety of its production. At the same time, countries with low rates of economic development have significant problems in ensuring effective food supply and the economic availability of meals.

The most significant factors influencing the food security of the population, expressed in the absence of precedent for hunger due to the inability to purchase food because of lack of funds, are:

- monthly income (negative correlation indicates that the higher the income, the less probability of respondent's hunger);

- value of prices when choosing food (direct correlation indicates that the more consumers consider the price of food, the greater the probability of the respondent's hunger);

- the number of family members (direct correlation indicates that the larger the size of the household, the greater the probability of the respondent's hunger);

- the number of famine-affected family members (direct correlation indicates that the more likely the hunger of a household member is, the greater the probability of a respondent's hunger), etc. 


\section{References}

Abdullah Zh., Shah T., Ali S., Ahmad W., Din I., Ilyas A. (2017). Factors affecting household food security in rural northern Hinterland of Pakistan // Journal of the Saudi Society of Agricultural Sciences. Vol. 93: 1-10. http://dx.doi.org/10.1016/j.jssas.2017.05.003

Agidev, A. and Singh, K. (2018). Determination of food insecurity in the rural farm households in South Wollo Zone of Ethiopia: the case of the Teleyayen sub-watershed // Agricultural and Food Economics Vol. 6:10. https://doi.org/10.1186/s40100-018-0106-4

Alexandria, C., Lucaa, L., and Kevorchiana, C. (2015). Subsistence economy and food security - the case of rural households from Romania // Procedia Economics and Finance. Vol.22: 672-680. https://doi.org/10.1016/S2212-5671(15)00282-8

Anema, A., Fielden, S., Castleman, T., Grede, N., Heap, A. and Bloem, M. (2014). Food Security in the Context of HIV: Towards Harmonized Definitions and Indicators // AIDS Behav. https://10.1007/s10461-013-0659-x

Babych, M. and Kovalenko, A. (2018).Food Security Indicators in Ukraine: Current State and Trends of Development // Baltic Journal of Economic Studies. Vol.4. No. 1: 8-15. https://doi.org/10.30525/2256-0742/2018-4-1-8-15

Blumberg, S., Bialostosky, K., Hamilton, W.and Briefel R. (1999). The Effectiveness of a Short Form of the Household Food Security Scale // American Journal of Public Health. Vol. 89. No. 8: 1231-1234.

Bruck, T. and d`Errico, M. (2019). Food security and violent conflict: Introduction to the special issue // World development. 167-171. https://doi.org/10.1016/j.worlddev.2019.01.007

Candel, J. (2018). Diagnosing integrated food security strategies // NJAS - Wageningen Journal of Life Sciences. Vol. 84: 103-113. http://dx.doi.org/10.1016/j.njas.2017.07.001

Chavas, J. (2017). On food security and the economic valuation of food // Food Policy. Vol. 69: 58-67. https://doi.org/10.1016/j.foodpol.2017.03.008

Cheeseman, J. (2016). Food Security in the Face of Salinity, Draught, Climate Changeand Population Growth // Halophytes for Food Security in Dry Lands. Vol. 23: 111-123. https://doi.org/10.1016/B978-0-12-801854-5.00007-8

Feleke, S., Kilmer, R and Gladwin, C. (2005). Determinants of food security in southern Ethiopia at the household level // Agricultural Economics. Vol. 33. No.3:352-363. https://doi.org/10.1111/j.1574-0864.2005.00074.x

GDP per capita (current US\$) World Bank national accounts data (2017). https://data.worldbank.org/indicator/NY.GDP.PCAP.CD?locations=UA\&name_desc=false \&view $=$ chart [2019 22 04].

Hidboro, M., Hoddinott, J., Kumar, N. and Olivier, M. (2018). Social Protection, Food Security, and Asset Formation // World Development. Vol.101: 88-103. https://doi.org/10.1016/j.worlddev.2017.08.014

Households Economic Conditions and Disparities (2018). http://dati.istat.it/index.aspx?lang=en\&SubSessionId=5221048b-ac34-4ca6-9074-762734811a78\# [2019 22 04].

Ickowitz, A., Powell, B., Rowland, D., Jones, A. and Sunderland T. (2019). Agricultural intensification, dietary diversity, and markets in the global food security narrative // Global Food Security. Vol. 20: 9-16. https://doi.org/10.1016/j.gfs.2018.11.002

Mwungu, C., Shikuku, K., Atibo, C. and Mwongera C. (2019). Survey-based data on food security, nutrition and agricultural production shocks among rural farming households in northern Uganda // Data in brief. Vol. 23: 248-257. https://doi.org/10.1016/j.dib.2019.103818

Leroy, J., Ruel, M., Frongillo, E., Harris, J. and Ballard, T. (2015). Measuring the Food Access Dimension of Food Security: A Critical Review and Mapping of Indicators // Food and Nutrition Bulletin. Vol. 36. No. 2: 167-195. https://doi.org/10.1177/0379572115587274 
Shebanina, O., Klyuchnik, A., Burkovska, A. and Caruso, D. (2018). Providing Labour Income as a Supporting Factor of the Food Security // Management Theory and Studies for Rural Business and Infrastructure Development. Vol. 40: 597-608. https://doi.org/10.15544/mts.2018.52

State Statistics Service of Ukraine (2019). - http://www.ukrstat.gov.ua [2019 22 04]. 